\title{
Fresh-cut Zucchini shelf-life after applying glutamic acid biofertilizer
}

\author{
Duración del calabacín con la aplicación de ácido glutámico \\ Jessica Welinski de O. D’Angelo ${ }^{*}$, Marcelle Michelloti Bettoni ${ }^{1}$, \\ Átila Francisco Mógor ${ }^{1}$, Francine Lorena Cuquel ${ }^{1}$
}

\begin{abstract}
The goal of this study was to increase the fresh-cut zucchini shelf-life with glutamic acid biofertilizer. Treatments consisted of foliar applications of aqueous solutions of the bacterial fermentation containing $30 \% \mathrm{~L}$-glutamic acid, at $14^{\text {th }}, 21^{\text {st }}, 28^{\text {th }}$, and $35^{\text {th }}$ days after transplanting, at 0.2 and $0.4 \mathrm{~mL} \mathrm{~L}^{-1}, 100 \mathrm{~mL}$ per plant of 7 days, starting at 14 days after transplant during the whole cycle (42 days). Zucchini fruits were pre-selected, sanitized and minimally processed into strips. Fruits were weighed (100 g) and placed into plastic bags of low density polyethylene $(70 \mu \mathrm{m})$. After sealing bags were stored. Plastic bags were kept at $6 \pm 1{ }^{\circ} \mathrm{C}$ and $95 \%$ relativity humidity. Weight loss, soluble solids content, $\mathrm{pH}$, titratable acidity, and color were performed at regular intervals of two days during eight days. To increase the fresh-cut zucchini shelf-life it is recommended to apply $0.4 \mathrm{~mL} \mathrm{~L}^{-1}$ glutamic acid biofertilizer.

Key words: Cucurbita pepo, summer squash, minimally processed, aminoacids, bacterial fermentation.
\end{abstract}

\section{RESUMEN}

El objetivo de este estudio fue evaluar el aumento de la vida útil del fruto de calabacín cortado fresco con el uso de ácido glutámico. Los tratamientos consistieron en aplicaciones foliares de soluciones acuosas de la fermentación bacteriana de ácido L-glutámico 30\%, a los 14,21, 28 y 35 días después del trasplante, en diferentes concentraciones $\left(0,2\right.$ y 0,4 mL L $\left.\mathrm{L}^{-1}\right)$, cada aplicación fue de $100 \mathrm{~mL}$. La primera aplicación foliar fue después de 14 días de realizado el trasplante en campo. En un ciclo total de 42 días. Posteriormente fueron preseleccionados los frutos, desinfectados y mínimamente procesados en tiras. Se usaron $100 \mathrm{~g}$ de fruto, colocados en bolsas de plástico de polietileno de baja densidad $(70 \mu \mathrm{m})$, selladas y almacenadas a $6 \pm 1{ }^{\circ} \mathrm{C}$ con humedad relativa del 95\%. Fue medido el peso, contenido de sólidos solubles, pH, acidez titulable y color, en intervalos regulares de dos días durante un total de ocho días. Se concluye que para aumentar la vida útil del calabacín recién cortado se recomienda aplicar $0,4 \mathrm{~mL} \mathrm{~L}^{-1}$ de ácido glutámico.

Palabras clave: Cucurbita pepo, calabaza de verano, mínimamente procesado, aminoácido, fermentación bacteriana.

\section{Introduction}

Recently fresh-cut vegetables (ready-to-eat) consume has increased due to its convenience (Lucera et al., 2010; Alves et al., 2010). However, these products have a shorter shelf-life than the whole one. It occurs because the surface damage resulting in dehidratation, color, flavor, aroma, volatile compounds changes (Vitti et al., 2005, Vilas Boas et al., 2006, Costa et al., 2011, Ngamchuachit et al., 2014; Evangelista et al., 2012; Gioppo et al., 2012).

Zucchini (Cucurbita pepo) is amongst the ten largest vegetable consumed in the Brazil (Lucio et al., 2008). It is a rich source of nutrients, especially natural antioxidants, including beta-carotene, folic acid and vitamins C and E (Lucera et al., 2010). However, when fresh-cut it is very perishable, with shelf-life limited to 1-2 days, due to firmness loss, browning and decay (Roura et al., 2004).

Biofertilizers is obtained from fermentation processes, such as the cane molasses brew by the bacterium Corynebacterium glutamicum, which contain the L-glutamic aminoacid. It has been studied in beans (Mógor et al., 2008), cabbage (Olinik et al., 2011), broccoli (Bettoni et al., 2013), and oregano (Bettoni et al., 2014). L-glutamic acid is

\footnotetext{
1 Universidade Federal do Paraná (UFPR), Departamento de Fitotecnia e Fitossanitarismo, Curitiba, PR, Brasil.

* Corresponding author: dangelo@ufpr.br
}

Fecha de Recepción: 15 Agosto, 2015.

Fecha de Aceptación: 20 Febrero, 2017.

DOI: $10.4067 / \mathrm{S} 0718-34292017005000010$ 
synthesized in plants by glutamine synthetase system/ glutamate synthase, and acts as a substrate for the transamination reactions (Tischner, 2000). Thus is related to nitrogen metabolism, leaf morphogenesis processes, and cell elongation (Yu et al., 2010).

L-glutamic aminoacid is appropriate to the organic and conventional production systems, however few studies applying this technology have been developed, mainly concerning with the product shelf-life. The goal of this study was to increase the fresh-cut zucchini shelf-life with glutamic acid biofertilizer.

\section{Material and Methods}

'Aline' Zucchini fruits were produced in Pinhais County, Paraná, Brazil (2523’30”S; 4907’30”W). Zucchini seedlings were planted on a Oxisol Alic, with the following average values in the $0-20 \mathrm{~cm}$ layer: $\mathrm{pH}\left(\mathrm{CaCl}_{2}\right)=5.9 ; \mathrm{pH}(\mathrm{SMP})=6.6 ; \mathrm{Al}^{3+}=0.0$; $\mathrm{H}+\mathrm{Al}^{3+}=3.2 \mathrm{cmol}_{\mathrm{c}} \mathrm{dm}^{-3} ; \mathrm{Ca}^{2+}=6.6 \mathrm{cmol}_{\mathrm{c}} \mathrm{dm}^{-3}$; $\mathrm{Mg}^{2+}=3.4 \mathrm{cmol}_{\mathrm{c}} \mathrm{dm}^{-3} ; \mathrm{K}^{+}=1.42 \mathrm{cmol}_{\mathrm{c}} \mathrm{dm}^{-3} ; \mathrm{P}=$ $88.5 \mathrm{mg} \mathrm{dm}^{-3} ; \mathrm{C}=35.1 \mathrm{~g} \mathrm{dm}^{-3} ; \mathrm{V}=78 \%$ and CTC $=14.62 \mathrm{cmol}_{\mathrm{c}} \mathrm{dm}^{-3}$.

\section{Planting and organic fertilization}

Foliar application of bacterial fermentation, containing 30\% of L-glutamic acid (Microquímica Chemical Ind. Ltda.), was applied on seedlings on $14^{\text {th }}, 21^{\text {st }}, 28^{\text {th }}$, and $35^{\text {th }}$ days after transplanting (DAT), at 0.2 and $0.4 \mathrm{~mL} \mathrm{~L}^{-1}, 100 \mathrm{~mL}$ per plant, with a manual sprayer with constant pressure (45 inch lib-2). Additionally a control treatment, with just water was applied. Field design was completely randomized, containing three doses, five replications of five plants per replication.

\section{Sampling, processing and shelf-life}

Fruit harvest was performed at $42 \mathrm{DAT}$, when they were 15 to 20 centimeters long, with brightgreen peel, and with any damage. They were washed with a neutral detergent, followed by sanitization with immersion in free chlorine solution (sodium hypochlorite) at $300 \mathrm{mg} \mathrm{L}^{-1}$ for 15 minutes, followed by drying at room temperature.

Zucchini fruits were cut into strips $1.0 \mathrm{x} 1.0 \mathrm{x}$ $5.0 \mathrm{~cm}$, followed by sanitization on free chlorine solution $\left(140 \mathrm{mg} \mathrm{L}^{-1}\right)$ at $5{ }^{\circ} \mathrm{C}$ during ten minutes, rinsing in chlorine solution $\left(5 \mathrm{mg} \mathrm{L}^{-1}\right)$ at $5{ }^{\circ} \mathrm{C}$, also during ten minutes, dipping in citric solutions $\left(1 \mathrm{mg} \mathrm{L}^{-1}\right)$ during four minutes, and dried with centrifuge. Samples were weighed $(100 \mathrm{~g})$, and stored in low density polyethylene $(70 \mu \mathrm{m})$ sealed bags $(24 \times 13 \mathrm{~mm})$ at $6 \pm 1{ }^{\circ} \mathrm{C}$ and $95 \%$ relative humidity. They were evaluated before to storage, and after 2, 4, 6, and 8 days.

Design applied was completely randomized in a factorial scheme with L-glutamic acid doses $\mathrm{x}$ shelf-life periods ( $3 \times 5)$, with three replications per treatment.

\section{Zucchini fresh-cut quality}

Mass loss

Zucchini fresh-cut daily mass was measured on the three sealed package per dose, from the initial mass, each other day, until eight days, and the mass loss was calculated as:

$$
\% \text { mass loss }=\frac{100-(\text { daily mass } \times 100)}{\text { initial mass }}
$$

\section{Color analysis}

Zucchini fresh-cut color was measured with an digital colorimeter from the initial day, each other day, until eight days, with three replications from each sample.

\section{pH, Titratable Acidity (TA) and Soluble Solids (SS)}

The $\mathrm{pH}$, titratable acidity (TA), and soluble solids content (SS), were measured on each sample according to IAL (2008).

\section{Statistical analysis}

Results were analyzed by the Bartlett Test, followed by regression analyses when it was applied.

\section{Results and Discussion}

Bacterial fermentation doses and storage period affected all attributes evaluated (Table 1 and Figures 1 and 2).

Mass loss is one the main process over the fresh-cut zucchini senescence (Lucera et al., 2010), such was verified here, because the highest mas 
Table 1. Analysis of variance of the effects of glutamic acid biofertilizer doses and storage periods (SP) of the variables mass loss (ML), titratable acidity (TA), soluble solids content (SS), $\mathrm{pH}$ and color $(\Delta \mathrm{E})$ in fresh-cut zucchini shelf-life.

\begin{tabular}{lcccccc}
\hline \multirow{2}{*}{ Covariate } & DF & \multicolumn{5}{c}{ Mean Square } \\
\cline { 3 - 6 } & & ML & TA & SS & pH & \multicolumn{1}{c}{$\Delta$ E } \\
\hline SP & 4 & $0.155^{* *}$ & $0.509^{* *}$ & $0.183^{* *}$ & $1.253^{* *}$ & $142.730^{* *}$ \\
Doses & 2 & $0.082^{* *}$ & $0.422^{* *}$ & $3.892^{* *}$ & $1.493^{* *}$ & $120.365^{* *}$ \\
SP x Doses & 8 & $0.006^{* *}$ & $0.130^{* *}$ & $0.065^{* *}$ & $0.037^{* *}$ & $133.204^{* *}$ \\
Residual & 30 & 0.001 & 0.281 & 0.005 & 0.002 & 1.239 \\
CV $(\%)$ & & 13.65 & 8.53 & 2.78 & 0.64 & 1.92 \\
\hline
\end{tabular}

** Represent significant at 0,001 probability levels.
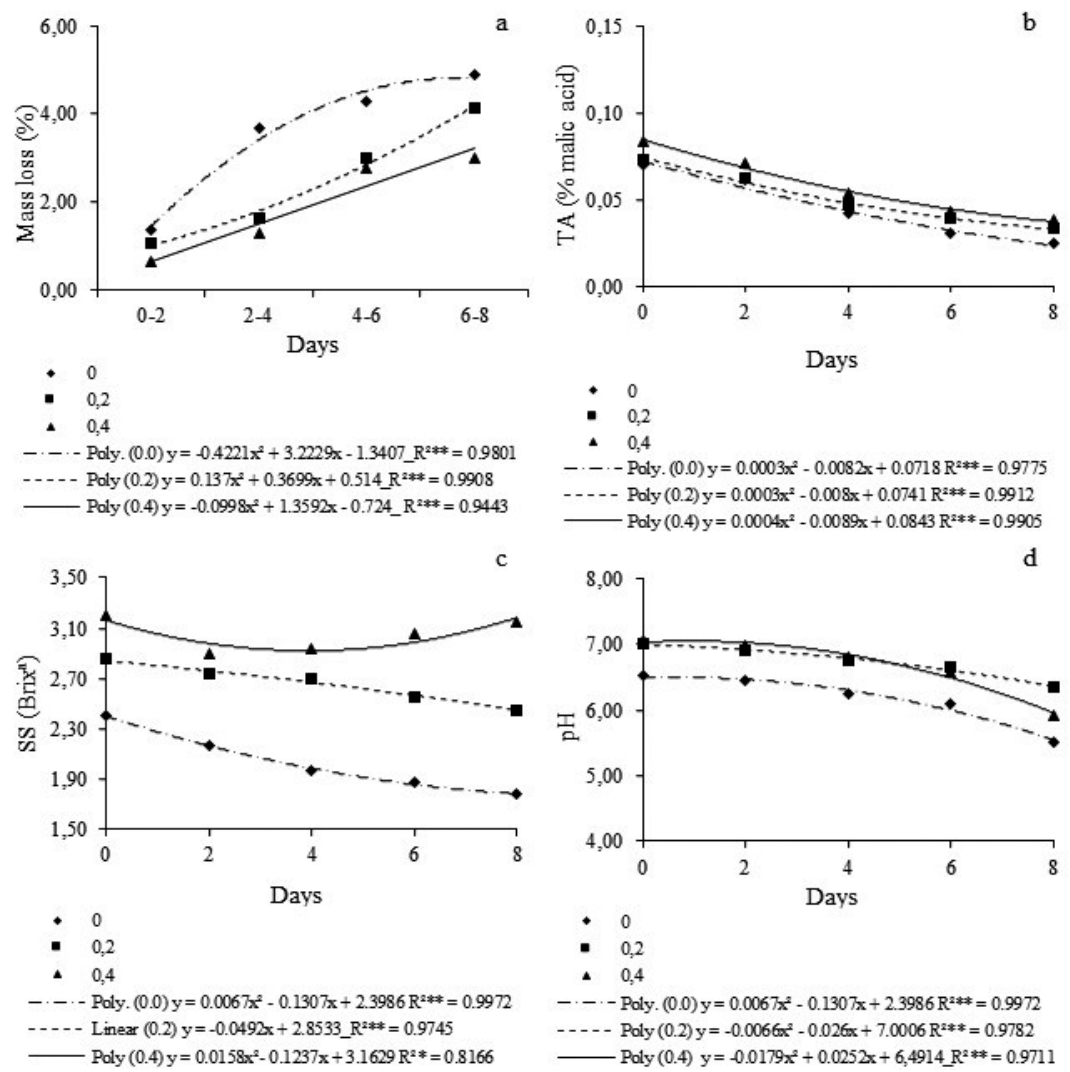

Figure 1. a) Mass loss (\%); b) titratable acidity (\% malic acid); c) soluble solids content ( ${ }^{\circ}$ Brix), and $\mathrm{d}) \mathrm{pH}$ in the fresh-cut zucchini shelf-life with glutamic acid biofertilizer during storage period.

loss occurred without applying L-glutamic acid (Figure 1a). It shows the importance of applying it on fresh-cut zucchini. L-glutamic acid doses showed similar behavior, with the best performance observed on $0.4 \mathrm{~mL} \mathrm{~L}^{-1}$. It might be related with the nitrogen increasing due to the L-glutamic acid, which causes collenchyma thickening, and decreases the water diffusion (Schuphan, 1974).
All L-glutamic acid doses decreased in the titratable acidity during the storage (Figure 2b). The concentration of acid organics during the storage tended to decrease, and the changes in postharvest vary according the acid, tissue, and handling and storage (Kays, 1991).

As shown in Figure 2c, the initial values of $\mathrm{pH}$ were highest to zucchini treated with 0.2 and $0.4 \mathrm{~mL} \mathrm{~L}^{-1}$ than others treatments. 


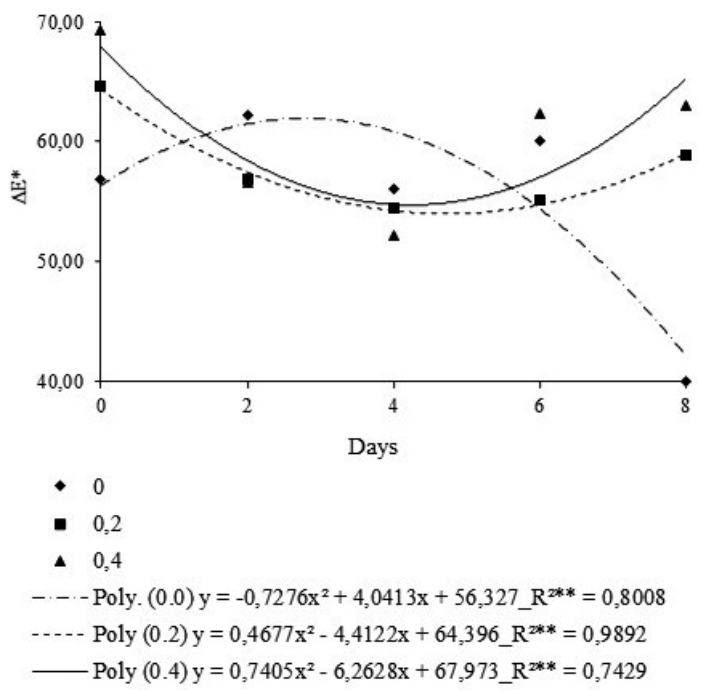

Figure 2. Effects of glutamic acid biofertilizer doses on color $(\Delta \mathrm{E})$ in the fresh-cut zucchini shelf-life during storage period.

The soluble solids content decrease were observed in fresh-cut zucchini with $0.2 \mathrm{~mL} \mathrm{~L}^{-1} \mathrm{~L}$-glutamic acid and treatment control (without biofertilizer) (Figure 2d), indicating the increased in the metabolism of fresh-cut zucchini. According Rinaldi \& Benedetti
(2004), carbohydrates are used as substrates in the respiratory process, and are principal components of soluble solids. The dose $0.4 \mathrm{~mL} \mathrm{~L}^{-1}$ showed increased in this content during the storage, indicating the effect of L-glutamic acid in the nitrogen metabolism by regulating the activities of key enzymes involved in nitrogen assimilation and catabolism, and led to the increase of photosynthetic capacity and soluble protein content (Yu et al., 2010). Asparagine and glutamate interconnect the two most important metabolic process, carbon cycle and nitrogen cycle, and these process influence the production of sugars and proteins, thus, L-glutamic acid supply is recommended for zucchini to improve photosynthetic processes and nitrogen metabolism (Taiz \& Zeiger, 2009)

The color $(\Delta \mathrm{E})$ (Figure 2) decreased on $0.2 \mathrm{~mL} \mathrm{~L}^{-1}$ and the control (without biofertilizer). However, the $0.4 \mathrm{~mL} \mathrm{~L}^{-1} \mathrm{~L}$-glutamic acid dose did not change during the storage period.

\section{Conclusions}

To increase the fresh-cut zucchini shelf-life it is recommended to apply $0.4 \mathrm{~mL} \mathrm{~L}^{-1}$ glutamic acid biofertilizer.

\section{Literature Cited}

Alves, J.A.; Barros Vilas Boas, E.V.B.; Souza, E.C.; Vilas Boas, B.M.;Piccoli, R.H.

2010. Vida útil de produto minimamente processado composto por abóbora, cenoura, chuchu e mandioquinha-salsa. Ciência e Agrotecnologia, 34 (1): 182-189.

Bettoni, M.M.; Fabbrin, E.G. dos S.; Olinick, J.R.; Mógor, A.F. 2013. Efeito da aplicação foliar de hidrolisado protéico sobre a produtividade de cultivares de brócolis. Revista Agro@mbiente On-line, 7: 179-183.

Bettoni, M.B.; Fabbrin, E.G. dos S.; Procopiuk, M.; Mógor, A.F. 2014. Crescimento de mudas de orégano submetidas a doses e frequências de aplicação de Ácido L-glutâmico em sistema orgânico. Revista Brasileira de Plantas Medicinais, 16: 83-88.

Chalot, M.; Blaudez, D.; Brun, A.

2006. Ammonia: a candidate for nitrogen transfer at the mycorrhizal interface. Trends in Plant Science, 11: 263-266.

Costa, F.B.; Duarte, P.S.; Puschmann R.; Finger, F.L.

2011. Quality of fresh-cut strawberry. Horticultura Brasileira, 29: 477-484.

Evangelista, R.M.; Manoel, L.; Costa, S.M.; Cardoso, A.I.I. 2012. Avaliação da qualidade pós-colheita da abobrinha submetida a diferentes tipos de cortes. Revista Iberoamericana de Tecnología Postcosecha, 13 (2): 187-195.

Gioppo, M.; Souza, A.M.; Gonçalves, J.; Ayub, R.A.

2012. Vida útil pós-colheita do repolho roxo minimamente processado, armazenado em diferentes embalagens. Revista Ceres, 59 (4): 560-564.
Instituto Adolf Lutz

2008. Normas Analíticas do Instituto Adolfo Lutz: Métodos químicos e físicos para análise de alimentos. IMESP. Sao Paulo, Brazil, 1020 p.

Jacomino, A.P.; Arruda, M.C.; Moreira, R.C.; Kluge, R.A.

2004. Processamento mínimo de frutas no Brasil. In: Simposium "Estado actual del mercado de frutos y vegetales cortados en Iberoamérica”, San José, Costa Rica, 79-86 pp.

Kays, S.J.

1991. Postharvest physiology of perishable plant products. Van Nostrand Reinhold, New York, US, 530 p.

King, B.J., Siddiqi, Y., Ruth, T.J., Warner, R.L.; Glass, A.D.M. 1993. Feedback regulation of nitrate influx in barley roots by nitrate, nitrite, and ammonium. Plant Physiology, 102 (4): 1279-1286.

Lucera, A.; Costa, C.; Mastromatteo, M.; Conte, A.; Del Nobile, M.A.

2010. Influence of different packaging systems on fresh-cut zucchini (Cucurbita pepo). Innovative Food Science and Emerging Technologies, 11: 361-368.

Lucio, A.D.; Carpes, R.H.; Storck, L.; Lopes, S.J.; Lorentz, L.H.; Paludo, A.L.

2008. Variância e média da massa de frutos de abobrinhaitaliana em múltiplas colheitas. Horticultura Brasileira, 26: $335-341$. 
Mógor, A.F; Ono, E.O.; Domingos, J.R.; Mógor, G. 2008. Aplicação foliar de extrato de alga, ácido l-glutâmico e cálcio em feijoeiro. Scientia Agraria, 9 (4): 431-437.

Ngamchuachit, P.; Sivertsen, H.K.; Mitcham, E.J.; Barrett, D.M. 2014. Effectiveness of calcium chloride and calcium lactate on maintenance of textural and sensory qualities of freshcut mangos. Journal of Food Science, 79 (5): 786-794.

Olinik, JR.; Mógor, A.F.; Röder, C.; Fabbrin, E.G.S.: Bettoni,

M.M.; Poletto, M.R.

2011. Frequência de aplicação de ácido L-glutâmico a $30 \%$ na qualidade de mudas de repolho. Horticultura Brasileira, 29: 4261-4264.

Rinaldi, M.M.; Benedetti, B.C.

2004. Influência de embalagem de polietileno de baixa densidade e da temperature na conservação do repolho minimamente processado. Engenharia Agrícola, 24 (2): 412-420.

Roura, S.I.; Moreira, M.; Del Valle, C.E.

2004. Shelf life of fresh-like ready-to-use diced squash. Journal of Food Quality, 27: 91-101.

Schuphan, W.

1974. Nutritional value of crops as influenced by organic and inorganic fertilizers treatments. Qualitas Plantarum, 13: 333-358.
Souza, F.; Argenta, L.C.; Nava, G.; Ernani; P.R.; Amarante, C.V.T.

2013. Qualidade de maçãs 'Fuji' influenciada pela adubação nitrogenada e potássica em dois tipos de solo. Revista Brasileira de Fruticultura, 35 (1): 305-315.

Taiz, L.; Zeiger, E.

2009. Fisiologia vegetal. Artmed. Porto Alegre, Brazil, 848 p.

Tischner, R.

2000. Nitrate uptake and reduction in higher and lower plants. Plant, Cell and Environment, 23 (10): 1005-1024.

Vilas Boas, B.M.; Nunes, E.E.; Vilas Boas, E.V.B.; Xisto, A.L.R.P. 2006. Influência do tipo de corte na qualidade de abobrinha 'Menina Brasileira' minimamente processada. Horticultura Brasileira, 24: 237-240.

Vitti, M.C.D.; Yamamoto, L.K.; Sasaki, F.F.; Aguila, J.S.; Kluge, R.A.; Jacomino, A.P.

2005. Quality of minimally processed beet roots stored in different temperatures. Brazilian Archives of Biology and Technology, 48 (4): 503-510.

Yu, C.; Lv, D.G.; Qin, S.J.; Yang, L.; Ma, H.Y.; Liu, G.C.

2010. Changes in photosynthesis, fluorescence, and nitrogen metabolism of hawthorn (Crataegus pinnatifida) in response to exogenous glutamic acid. Photosynthetica, 48 (3): 339-347. 
